\title{
Bilateral megalocystic ovaries following in vitro fertilization detected during cesarean section: a case presentation
}

\author{
In Vitro Fertilizasyonu Takiben Sezaryen Esnasinda Tespit Edilen Bilateral \\ Megalokistik Overler: Olgu Sunumu
}

\author{
Hüsnü Alptekin ${ }^{1}$ Kazım Gezginç ${ }^{2}$, Fatma Yazıcı Yılmaz ${ }^{2}$ \\ 'Department of Gynecology and Obstetrics, Mevlana Private Hospital, Konya, Turkey \\ ${ }^{2}$ Department of Gynecology and Obstetrics, Meram Faculty of Medicine, Selçuk University, Konya, Turkey
}

\section{Abstract}

We present a patient with persistent bilateral megalocystic ovaries following in vitro fertilization which was detected during cesarean section. A 24 year-old primigravida presented to our clinic at the $36^{\text {th }}$ week of a twin pregnancy with labour pain and cervical dilatation. On ultrasound examination, 2 masses of $90 \times 60$ and $60 \times 70 \mathrm{~mm}$ were seen in the right and left adnexal regions respectively. Her history showed that she had unexplained infertility for 4 years and had undergone IVF with gonadotropin releasing hormone (GnRH)-agonist stimulation. Two embryos were transferred. Twin pregnancy was detected on ultrasound examination. The patient was delivered by emergency caesarean section due to transverse presentations at $36^{\text {th }}$ weeks of gestation. During the operation, both adnexae were markedly enlarged, the right ovary measuring about $15 \times 18 \mathrm{~cm}$ and the left about $16 \times 18 \mathrm{~cm}$. There was minimal ascites in the abdominal cavity. Ovarian biopsy was performed and the final pathology report showed bilateral follicle cysts. The patient was discharged on the postoperative $4^{\text {th }}$ day. The patient was seen 4 weeks later. She had no complaints and ultrasound follow-up revealed a normal size uterus and ovaries. We should keep in mind that hyperstimulated, enlarged ovaries and its complication may be seen in the late weeks of pregnancy, even at term, in cases of in vitro fertilization cases. Therefore, close follow-up of pregnant IVF patints is recommended whether they had OHSS or not, because ovarian torsion caused by hyperstimulated ovaries may be difficult to diagnose during pregnancy.

(J Turkish-German Gynecol Assoc 2012; 13: 142-4)

Key words: Bilateral megalocystic ovaries, in vitro fertilization, term pregnancy, OHSS, cesarean delivery

Received: 5 August, 2011

Accepted: 8 October, 2011
Özet

İn Vitro Fertilizasyon (IVF) sonrası sezaryen esnasında persiste bilateral megalokistik overlerin tespit edildiği bir hastayı sunuyoruz. 24 yaşında 36. gebelik haftasında ikiz gebelik ve ilk gebeliği olan hasta doğum sancısı ve servikal dilatasyon ile kliniğimize başvurdu. Ultrasonografik incelemesinde sağ ve sol adneksiyal bölgede $90 \times 60 \mathrm{~mm}$ ve $60 \times 70$ mm boyutunda iki adet kitle izlendi. Hastanın öyküsünden 4 yıllık açıklanamayan infertilitesinin olduğu ve GnRH agonist stimülasyonla IVF tedavisine alındığı öğrenildi. İki embryo transferi yapıldı ve ultrasonografide ikiz gebelik tespit edildi. Hasta transvers presentasyon sebebi ile 36. gebelik haftasında acil sezaryen ile doğum gerçekleştirildi. Operasyonda, her iki adneksial bölge büyümüş, sağ over $15 \times 18 \mathrm{~cm}$ sol over $16 \times 18 \mathrm{~cm}$ olarak ölçüldü. Abdominal kavitede minimal asit mevcuttu. Ovarian biopsi yapıldı ve son patolojik tanı follikül kisti olarak geldi. Hasta postoperatif 4. gününde taburcu edildi. Hasta 4 hafta sonra tekrar görüldü. Hastanın şikayeti yoktu ve ultrasonografi takibinde uterus ve overler normal boyutta idi. IVF olgularında, hiperstimüle, büyümüş overler ve komplikasyonlarının geç gebelik haftalarında veya termde gözlenebileceği de akılda tutulmalıdır. Hiperstimüle overlerin ovarian torsiyona sebep olabileceği ve gebelikte tespiti zor olması sebebi ile IVF gebelerinin OHSS olsun veya olmasın sıkı takibi yapılmalıdır.

(J Turkish-German Gynecol Assoc 2012; 13: 142-4)

Anahtar kelimeler: Bilateral megalokistik overler, in vitro fertilizasyon, term gebelik, OHSS, sezaryen doğum

Geliş Tarihi: 05 Ağustos 2011

Kabul Tarihi: 08 Ekim 2011

\section{Introduction}

Ovarian hyperstimulation syndrome (OHSS) is a potential complication of ovarian stimulation in the treatment of infertility. Severe forms of OHSS appear in $0.5-5.0 \%$ of in vitro fertilization (IVF) cycles (1). The syndrome has been known since 1943 when gonadotrophins were first used to induce ovulation (2).

Typically, iatrogenic OHSS is diagnosed immediately following conception. One of the presentations of ovarian hyperstimu- lation syndrome (OHSS) is an increase in ovarian size and the presence of numerous luteal cysts (3). Hyperstimulated ovaries often subside when the hCG levels start to decline at 10-12 weeks and rarely continue until 20 weeks. Pregnancies complicated by OHSS were observed in the $2^{\text {nd }}$ and $3^{\text {rd }}$ trimesters $(2,4,5)$; but only two cases were reported with OHSS recognized during cesarean section or during the postpartum period $(3,6)$.

We aimed to present a patient with persistent bilateral megalocystic ovaries detected during cesarean section which was 
performed for transverse presentation in the $36^{\text {th }}$ weeks of a twin pregnancy induced by gonadotropins.

\section{Case Presentation}

A 24 year-old primigravida presented to our clinic on $36^{\text {th }}$ week of a twin pregnancy, with labour pains and cervical dilatation. On ultrasound examination, two viable fetuses with biometrical measurements consistent with 35 weeks were seen, the amniotic fluid was normal and the placenta anteriorly located. Two masses of 90x60 and 60x70 mm were seen in the right and left adnexal regions, respectively. The large uterus due to the 36 week gestation limited the ultrasonographic evaluation of the ovaries so they were measured as smaller than the actual size encountered during operation. Her history showed that she had unexplained infertility for 4 years and had undergone several attempts for ovulation induction and intrauterine insemination. These were unsuccessful, so she underwent IVF with gonadotropin releasing hormone (GnRH)-agonist stimulation, and 225 IU recombinant follicle-stimulating hormone (Gonal-F; Serono, Istanbul) was started on the second day of the menstrual cycle. Transvaginal oocyte retrieval was carried out on day 16 , yielding 17 mature oocytes. Two embryos were transferred. The patient did not have any signs or symptoms of OHSS during her pregnancy. Twin pregnancy was detected on ultrasound examination. Deep vein thrombosis was detected at the $32^{\text {nd }}$ week and subcutaneous Enoxaparin Sodyum 0.8cc 1x2 (Clexane ${ }^{\circledR}$, Aventis, Istanbul) was started twice daily. There was no other problem during pregnancy. The IVF procedure and pregnancy follow up were carried out in another centre. The patient was delivered in our hospital by emergency caesarean section due to transverse presentations and she had labour pain and cervical dilatation at the $36^{\text {th }}$ week of gestation. A male and a female baby were delivered. During the operation, both adnexae were markedly enlarged, the right ovary measuring about $15 X 18 \mathrm{~cm}$ and the left about $16 \times 18 \mathrm{~cm}$ (Figure 1). There was minimal ascites in the abdominal cavity. Ovarian biopsy was performed

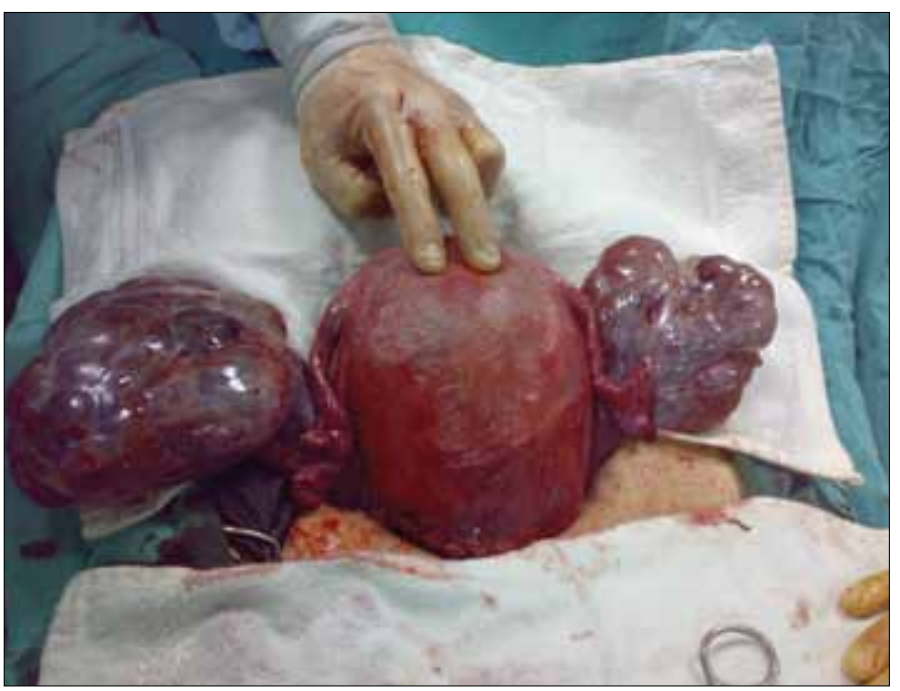

Figure 1. Both ovaries were markedly enlarged, the right ovary measuring about $15 \times 18 \mathrm{~cm}$ and the left about $16 \times 18 \mathrm{~cm}$ and the final pathology report showed bilateral follicular cysts. The postoperative course was uneventful, and the patient was discharged on the $4^{\text {th }}$ postoperative day. The patient was seen 4 weeks later. She had no complaint and an ultrasound follow-up revealed a normal sized uterus and ovaries.

\section{Discussion}

OHSS continues to be a serious complication of assisted reproductive therapy (ART). There are well-known risk factors that must be considered during the administration of medications to treat infertility (1).

Ovarian enlargement secondary to hyperstimulation is common. Human chorionic gonadotropin (hCG) stimulates the ovaries to continue to grow (3). If no pregnancy occurs, the syndrome will typically resolve within 1 week. If the pregnancy continues, slow resolution of symptoms of luteal cysts usually occurs over 1-2 months and rarely persists until 5 months of gestation. This is probably because of continuous exposure of the ovaries to endogenous hCG. Ovarian enlargement with multiple follicular and lutein cysts persists for a longer period if pregnancy continues. Hyperstimulated ovaries often subside in the $20^{\text {th }}$ week of gestation (3). Endogenous hCG is secreted by the trophoblast starting 7-8 days after fertilization. In a normal singleton pregnancy hCG concentration in the maternal serum reaches a peak level of $100000 \mathrm{IU} / \mathrm{L}$ between 8-10 weeks of gestation, and declines to $40000 \mathrm{IU} / \mathrm{L}$ from 20 weeks up to delivery $(4,7)$.

He et al. (6) presented an interesting case of spontaneous severe OHSS after delivery. Ling et al. (3) reported a case of persistent megalocystic ovaries during the cesarean section in a patient with an IVF pregnancy. The megalocystic ovaries persisted after delivery so the patient was operated on again and biopsies from both ovaries were performed, and the histopathological result was follicular cyst. Our case was interesting because the patient was not diagnosed as OHSS and there was no symptom of OHSS or enlarged ovaries during pregnancy. We expect bilateral megalocystic ovaries to subside after the first trimester. However, in this case, enlargement of ovaries continued until the $36^{\text {th }}$ week of gestation. The ovaries in our patient regressed in the $1^{\text {st }}$ month of postpartum period.

Some researches show that, in patients with regular ovulatory cycles, improvement of symptoms of OHSS is obtained in a shorter time than in patients with anovulatory cycles before pharmacological induction (8). In our case, inducing ovulation by gonadotropins, and high hCG due to twin pregnancy could be factors that delayed the decrease of ovarian size. However, in our search of the literature, we did not find any case report of persisting megalocystic ovaries reaching term in IVF patients. A variety of cystic ovarian conditions may develop during pregnancy. The differential diagnosis of multicystic ovaries during pregnancy includes ovarian hyperstimulation, hyperreactioluteinalis, theca lutein cysts, and polycystic ovarian syndrome (PCOS). Some researchers demonstrated a relationship between infertility treatment and the risk of inducing ovarian cancer (9). This risk of malignancy should be kept in mind but should not lead to unnecessary surgery. In our case; because 
the patient had infertility treatment, we thought that the ovarian enlargement may be due to OHSS secondary to ovulation induction.

Many rare complications of ovarian enlargement, such as ovarian torsion and labor dystocia, may be seen in ovary-expanding conditions (4). Ovulation induction techniques predispose to ovarian cyst formation, particularly if ovarian hyperstimulation syndrome (OHSS) is present; therefore, it is to be expected that women undergoing gonadotropin ovulation induction are at increased risk of adnexal torsion (10). Cornfeld et al. (11) reported two cases of ovarian torsion complicating ovarian hyperstimulation in 7 week pregnant patients, one of them was a twin pregnancy.

The reduction in ovarian volume and the resolution of ascites, along with gradual symptomatic relief, observed during careful clinical and ultrasonic follow-up, contribute to the decision for close observational management (4). Our patient had normal ovarian size on ultrasound examination after one month.

In conclusion, we should keep in mind that hyperstimulated, enlarged ovaries and its complications may be seen in the late weeks of pregnancy even at term in cases of in vitro fertilization cases. So close follow-up of pregnant IVF patients is recommended whether they had OHSS or not because ovarian torsion caused by hyperstimulated ovaries may be difficult to diagnose during pregnancy.

\section{Conflict of interest}

No conflict of interest was declared by the authors.

\section{References}

1. Chen SU, Chen CD, Yang YS. Ovarian hyperstimulation syndrome (OHSS): new strategies of prevention and treatment. J Formos Med Assoc 2008; 107: 509-12. [CrossRef]
2. Baksu A, Baksu B, Goker N. Laparoscopic unwinding and cyst aspiration of an ovarian torsion in spontaneous ovarian hyperstimulation syndrome associated with a singleton pregnancy. Aust $\mathrm{N} \mathrm{Z} \mathrm{J}$ Obstet Gynaecol 2004; 44: 270-2. [CrossRef]

3. Ling SY, Chong KM, Hwang JL. Persistent megalocystic ovary following in vitro fertilization in a postpartum patient with polycystic ovarian syndrome. Taiwan J Obstet Gynecol. 2006; 45: 70-2. [CrossRef]

4. Haimov-Kochman R, Yanai N, Yagel S, Amsalem H, Lavy Y, Hurwitz A. Spontaneous ovarian hyperstimulation syndrome and hyperreactio luteinalis are entities in continuum. Ultrasound Obstet Gynecol 2004; 24: 675-8. [CrossRef]

5. Maschiach S, Bider D, Moran O, Goldenberg M, Ben-Rafael Z. Adnexal torsion of hyperstimulated ovaries in pregnancies after gonadotropin therapy. Fertil Steril 1990; 53: 76-80.

6. He C, Huang H, Song Y. Spontaneous and severe ovarian hyperstimulation syndrome after delivery: a case report. Gynecol Endocrinol. 2008; 24: 450-1. [CrossRef]

7. Ludwig M, Gembruch U, Bauer O, Diedrich K. Ovarian hyperstimulatio syndrome (OHSS) in a spontaneous pregnancy with fetal and placental triploidy: information about the general pathophysiology of OHSS. Hum Reprod 1998; 13: 2082-7. [CrossRef]

8. Cobellis L, Pecori E, De Lucia E, Pierno G, Stradella L, Severi FM, et al. Regression of ovarian enlargement in pharmacological ovulation induction. Gynecol Endocrinol 2001; 15: 239-42. [CrossRef]

9. Salle B, de Saint Hilaire P, Devouassoux M, Gaucherand P, Rudigoz C. Another two cases of ovarian tumours in women who had undergone multiple ovulation induction cycles. Hum Reprod. 1997; 12: 1732-5. [CrossRef]

10. Child TJ, Watson NR, Ledger WL. Sequential bilateral adnexal torsion after a single cycle of gonadotropin ovulation induction with intrauterine insemination. Fertil Steril. 1997; 67: 573-5. [CrossRef]

11. Cornfeld D, Scoutt L. Torsion of a hyperstimulated ovary during pregnancy: a potentially difficult diagnosis. Emerg Radiol 2007; 14: 331-5. [CrossRef] 